\title{
Pengaruh Struktur Modal Terhadap Profitabilitas (Studi Pada Perusahaan Pertambangan Yang Terdaftar di Bursa Efek Indonesia Periode 2011-2015)
}

\author{
Mitha Rahma Fauzan ${ }^{1 *}$ dan Mukaram ${ }^{2}$ \\ ${ }^{1}$ Jurusan Administrasi Niaga, Politeknik Negeri Bandung, Indonesia \\ 2 Jurusan Administrasi Niaga, Politeknik Negeri Bandung, Indonesia
}

\begin{abstract}
:
Capital structure is one of the issue that attract many researchers in the field of finance and an important issue for any company because of its capability to directly effect on companies' financial position. This study aims to determine the effect of debt to equity ratio (DER) and debt to assets ratio (DAR) as the dimension of capital structure to return on equity (ROE) and return on assets (ROA) as dimensions of company profitability ratios, either simultaneously or partially on mining companies listed in Indonesia Stock Exchange period 2011-2015. This research was conducted by using multiple linear regression analysis and yielded two equations of regression model. The data obtained are secondary data using documentation method. The result of regression analysis shows that the two dimensions of capital structure have significant effect to both dimensions of profitability simultaneously. While partially, only DAR which have a significant effect on the ROE and ROA.
\end{abstract}

Keywords: capital, debt, equity, profitability

\begin{abstract}
Abstrak:
Struktur modal merupakan salah satu isu yang menarik banyak peneliti di bidang keuangan dan isu penting bagi perusahaan karena kemampuan struktur permodalan untuk mempengaruhi secara langsung posisi finansial perusahaan tersebut. Penelitian ini bertujuan untuk mengetahui pengaruh rasio hutang terhadap ekuitas (DER) dan rasio hutang terhadap asset (DAR) sebagai dimensi struktur modal terhadap return on equity (ROE) dan return on assets (ROA) sebagai dimensi rasio profitabilitas perusahaan, baik secara simultan maupun parsial pada perusahaan pertambangan yang terdaftar di Bursa Efek Indonesia periode 2011 2015. Penelitian ini dilakukan dengan menggunakan analisis regresi linier berganda dan menghasilkan dua persamaan model regresi. Data yang diperoleh adalah data sekunder dengan menggunakan metode dokumentasi. Hasil analisis regresi menunjukkan bahwa kedua dimensi struktur modal berpengaruh signifikan terhadap kedua dimensi profitabilitas secara simultan. Sementara sebagiannya, hanya dimensi DAR yang menunjukkan pengaruh signifikan terhadap dimensi ROE dan ROA.
\end{abstract}

Kata Kunci: modal, hutang, ekuitas, profitabilitas

\section{PENDAHULUAN}

Pertumbuhan ekonomi Indonesia yang mengalami penurunan dari tahun 2013

*Email korespondensi:

Mitha Rahma Fauzan

mitharahmafauzan@gmail.com hingga tahun 2015 mengakibatkan perlambatan pertumbuhan di semua sektor ekonomi, khususnya pertumbuhan sektor pertambangan dan penggalian tercatat paling kecil pada tahun 2013. Perlambatan pertumbuhan perusahaan pertambangan 
mengakibatkan jumlah produksi barang tambang mineral pada tahun terkait kian menurun. Produksi barang tambang mineral mengalami penurunan pada tahun 2014 dan 2015 disebabkan oleh harga batu bara di pasar internasional yang terus menurun, hal tersebut membuat beberapa perusahaan batu bara berhenti beroperasi dan tutup sementara. Perlambatan pertumbuhan perusahaan pertambangan tersebut membuat setiap perusahaan dituntut untuk membuat rencana strategis pada semua aspek perusahaan, tidak terkecuali aspek yang berkaitan dengan keputusan pendanaan.

Urgensi keputusan pendanaan yang tepat pun dipicu oleh kebijakan Pemerintah yang menetapkan Undang-undang Nomor 4 Tahun 2009 tentang Pertambangan Mineral dan Batubara, yang menjelaskan bahwa pemegang Izin Usaha Pertambangan (IUP) operasi produksi dan pemegang kontrak karya wajib melakukan peningkatan nilai tambah mineral melalui kegiatan pengolahan dan pemurnian di dalam negeri selambatlambatnya 5 (lima) tahun sejak UU No. 4 Tahun 2009 diundangkan. Untuk membangun pemurnian hasil tambang (smelter) tersebut, pemerintah menyarankan pengusaha pertambangan dapat mengajukan pinjaman dari perbankan asing dan nasional.

Dalam memilih alternatif pendanaan untuk membiayai kegiatan perusahaan, maka yang akan menjadi pertimbangan adalah bagaimana perusahaan dapat menciptakan kombinasi yang menguntungkan antara penggunaan dana dari modal saham dengan dana yang berasal dari utang. Hal ini menyangkut masalah keberadaan struktur modal perusahaan yang menggambarkan pengaturan komposisi modal yang tepat antara jumlah utang dengan jumlah ekuitas perusahaan, perimbangan tersebut biasa disebut Debt to Equity Ratio (DER). Struktur modal merupakan imbangan antara modal asing atau utang dengan modal sendiri. Sedangkan salah satu ukuran keberhasilan manajemen perusahaan adalah profitabilitas.
Menurut Brigham dan Houston (2011:155) "profitability is the result of a large number of policies and decision". Menurut Rufaidah (2012) rasio profitabilitas dapat mengukur keefektifan manajemen secara keseluruhan sebagaimana ditunjukkan oleh pengembalian (return) yang diperoleh dari penjualan dan investasi. Pengembalian tersebut dapat diukur oleh rasio kemampuan aset perusahaan dalam menghasilkan laba dan kemampuan modal perusahaan dalam menghasilkan sejumlah laba, rasio atas pengembalian tersebut biasa disebut Return on Assets (ROA) dan Return on Equity (ROE). Semakin besar rasio akan semakin baik karena kesejahteraan pemegang saham meningkat dengan semakin besarnya profitabilitas.

Penelitian ini dilakukan di sektor pertambangan yang terdaftar di Bursa Efek Indonesia periode tahun 2011-2015. Karakteristik sektor pertambangan yang memiliki risiko tinggi menyebabkan sektor ini dapat memberikan return yang tinggi. Menurut Brigham dan Houston (2011), penggunaan utang yang lebih besar biasanya akan menyebabkan terjadinya ekspektasi tingkat pengembalian atas ekuitas yang lebih tinggi. Namun, yang terjadi pada beberapa perusahaan pertambangan yang terdaftar di Bursa Efek Indonesia adalah total utang pada tahun 2013-2015 kian meningkat namun harga saham kian menurun. Oleh karena itu, dapat diindikasikan bahwa struktur modal pada perusahaan pertambangan yang tercatat di Bursa Efek Indonesia tahun 2013-2015 menyebabkan turunnya profitabilitas perusahaan.

\section{KAJIAN LITERATUR Struktur Modal}

Weston dan Copeland dalam Fahmi (2013) menyatakan bahwa capital structure or the capitalization of the firm is the permanent financing represented by longterm debt, preferred stock, and shareholder's equity. Sedangkan menurut Brigham dan Houston (2011:155) mengatakan "sasaran struktur modal 
(optimal capital structure) suatu perusahaan didefinisikan sebagai struktur yang akan memaksimalkan harga saham perusahaan tersebut". Selanjutnya menurut Sudana (2011) struktur modal (capital structure) berkaitan dengan pembelanjaan jangka panjang suatu perusahaan yang diukur dengan perbandingan utang jangka panjang dengan modal sendiri. Jadi, berdasarkan definisi di atas dapat ditarik kesimpulan bahwa struktur modal merupakan kombinasi antara utang dan ekuitas yang dimiliki oleh perusahaan dan dijalankan untuk aktivitas perusahaan. Dalam struktur keuangan jangka panjang perusahaan, struktur modal mencerminakan perimbangan antara total utang dengan modal sendiri.

\section{Teori Menyangkut Struktur Modal}

Terdapat beberapa teori terkait dengan keputusan struktur modal. Pertama, teori Miller dan Modigliani atau yang dikenal dengan teori M\&M. Menurut Megginson dalam Mulyawan (2015) teori M\&M secara eksplisit mengakui tidak adanya hubungan dari pendanaan dan investasi. Dalam arti bahwa menggunakan utang atau tanpa utang dalam mendanai investasi perusahaan tidak berpengaruh terhadap perubahan nilai perusahaan.

Kedua, teori pertukaran (trade-off theory) menurut Brigham dan Houston (2011) adalah teori struktur modal yang menyatakan bahwa perusahaan menukar manfaat pajak dari pendanaan utang dengan masalah yang ditimbulkan oleh potensi kebangkrutan. Ketiga, teori sinyal (signaling theory) Signalling menurut Mulyawan (2015) merupakan kegiatan pendanaan manajer yang dipercaya dapat merefleksikan nilai dari saham perusahaan. Pada umumnya pendanaan dengan utang dianggap sebagai sinyal positif sehingga manajer percaya bahwa saham undervalued. Hubungannya dengan profitabilitas adalah suatu perusahaan yang memprediksi labanya rendah akan cenderung untuk menggunakan tingkat utang yang rendah.
Keempat, teori pecking order. Pecking-order theory berangkat dari kondisi asymmetric information. Asymmetric information menurut Prihadi (2013) adalah istilah popular yang menyatakan bahwa manajemen dianggap lebih tahu kondisi perusahaan dibandingkan dengan investor.

\section{Profitabilitas}

Rasio profitabilitas menurut Ross, Westerfield, Jordan, Lam, \& Tan (2015) rasio profitabilitas merupakan rasio untuk mengukur seberapa efisien suatu perusahaan dalam memanfaatkan asetnya dan mengelola kegiatan operasinya. Selanjutnya menurut Gitman \& Zutter (2015) profitability ratios measures enable analysts to evaluate the firm's profits with respect to a given level of sales, a certain level of assets, or the owners' Assets. Sedangkan rasio profitabilitas menurut Kasmir (2008) merupakan rasio untuk menilai perusahaan dalam mencari keuntungan. Berdasarkan beberapa pengertian dari para ahli di atas dapat disimpulkan bahwa profitabilitas adalah rasio yang digunakan untuk menilai dan mengukur kinerja perusahaan dalam hal seberapa efisien perusahan dalam mengelola asetnya dalam menghasilkan laba, sehingga tingkat keuntungan perusahaan dapat diukur dari waktu ke waktu.

\section{Tujuan dan Manfaat Rasio Profitabilitas}

Penggunaan rasio profitabilitas dapat dilakukan dengan menggunakan perbandingan antara berbagai komponen yang ada di laporan keuangan, teruma laporan keuangan neraca dan laporan laba rugi. Adapun tujuan penggunaan rasio profitabilitas bagi perusahaan maupun bagi pihak luar perusahaan menurut Kasmir (2008), yaitu:

1. Untuk mengukur atau menghitung laba yang diperoleh perusahaan dalam satu periode tertentu

2. Untuk menilai posisi laba perusahaan tahun sebelumnya dengan tahun sekarang

3. Untuk menilai perkembangan laba dari waktu ke waktu 
4. Untuk menilai besarnya laba bersih sesudah pajak dengan modal sendiri

5. Untuk mengukur produktivitas seluruh dana perusahaan yang digunakan baik modal pinjaman maupun modal sendiri

6. Untuk mengukur produktivitas dari seluruh dana perusahaan yang digunakan baik modal sendiri

Sementara itu, manfaat yang diperoleh adalah untuk:

1. Mengetahui besarnya tingkat laba yang diperoleh perusahaan dalam satu periode

2. Mengetahui posisi laba perusahaan tahun sebelumnya dengan tahun sekarang

3. Mengetahui perkembangan laba dari waktu ke waktu

4. Mengetahui besarnya laba bersih sesudah pajak dengan modal sendiri

5. Mengetahui produktivitas dari seluruh dana perusahaan yang digunakan baik modal pinjaman maupun modal sendiri

\section{Hubungan Struktur Modal terhadap Profitabilitas}

Dalam penelitian Salawu (2009), dapat disimpulkan bahwa dampak struktur modal terhadap profitabilitas tidak signifikan tapi terdapat hubungan positif antara profitabilitas dengan utang jangka pendek. Hasilnya menunjukkan bahwa perusahaan di Nigeria tergantung pada pendanaan eksternal. Dalam kasus Nigeria ini, proporsi yang tinggi sebesar $60 \%$ dari utang diwakili dalam utang jangka pendek.

Selanjutnya dalam penelitian Velnampy dan Niresh (2012) dapat disimpulkan bahwa bank di Sri Lanka lebih tergantung pada utang jangka panjang daripada modal. Nilai $\mathrm{R}$ pada penelitian ini adalah $-0.661,-0.879$, dan -0.711 , ini mengungkapkan bahwa meningkatkan pembayaran bunga utang dapat mengakibatkan penurunan profitabilitas.

Sedangkan menurut penelitian Addae, Baasi, Hughes (2013), Dapat disimpulkan bahwa terdapat hubungan positif yang signifikan secara statistik antara utang jangka pendek dan profitabiitas. Di lain sisi terdapat hubungan negatif yang signifikan secara statistik antara profitabilitas dan utang jangka panjang dan terdapat hubungan negatif yang signifikan secara statistik antara profitabiltias dan total utang keseluruhan.

\section{Hipotesis Penelitian}

Menurut Nazir (2013) hipotesis adalah pernyataan yang diterima secara sementara sebagai suatu kebenaran sebagaimana adanya, pada saat fenomena dikenal dan merupakan dasar kerja serta panduan dalam verifikasi.

Untuk mengukur struktur modal dapat diketahui dari rasio Debt to Equity (DER), Debt to Asset Ratio (DAR), dan Long Term Debt Ratio (Sjahrial dan Purba, 2013). Namun dalam penelitian ini dimensi Long Term Debt Ratio tidak digunakan karena tidak semua perusahaan pertambangan yang terdaftar di Bursa Efek Indonesia periode tahun 2011-2015 mempunyai Long Term Debt sehingga dimensi yang digunakan adalah dimensi Debt to Equity Ratio (DER) dan Debt to Total Assets (DAR). Sedangkan untuk untuk mengukur profitabilitas perusahaan menurut Ross, Westerfield, Jordan, Lam, \& Tan (2015) adalah Return on Equity (ROE), Return on Assets (ROA), dan Net Profit Margin (NPM), namun dalam penelitian ini dimensi Net Profit Margin (NPM) tidak digunakan karena terdapat beberapa perusahaan memiliki NPM 0,00 atau dapat dikatakan bahwa pada tahun terkait perusahaan tidak melakukan penjualan sehingga dimensi yang digunakan adalah dimensi Return on Equity (ROE) dan Return on Assets (ROA). Sehingga dapat dirumuskan hipotesis penelitian sebagai berikut:

$\mathrm{H}_{1}$ : Debt to Equity Ratio (DER) dan Debt to Assets Ratio (DAR) secara simultan berpengaruh signifikan terhadap Return on Equity (ROE)

$\mathrm{H}_{2}$ : Debt to Equity Ratio (DER) dan Debt to Assets Ratio (DAR) secara simultan berpengaruh signifikan terhadap Return on Assets (ROA) 
$\mathrm{H}_{3}$ : Debt to Equity Ratio (DER) dan Debt to Assets Ratio (DAR) secara parsial berpengaruh signifikan terhadap Return on Equity (ROE)

$\mathrm{H}_{4}$ : Debt to Equity Ratio (DER) dan Debt to Assets Ratio (DAR) secara parsial berpengaruh signifikan terhadap Return on Assets (ROA)

\section{METODE PENELITIAN}

\section{Operasional Variabel Penelitian}

Variabel bebas (independent variable) merupakan variabel yang mempengaruhi atau yang menjadi sebab perubahan atau timbulnya variabel terikat (Sugiyono, 2014). Sedangkan variabel terikat (dependent variable) adalah variabel yang dipengaruhi atau yang menjadi akibat, karena adanya variabel bebas. Dalam penelitian ini yang merupakan variabel bebas adalah struktur modal yang akan diukur dengan dimensi Debt to Equity Ratio (DER) dan Debt to Assets Ratio (DAR) sedangkan yang menjadi variabel terikat adalah profitabilitas yang akan diukur dengan dimensi Return on Equity (ROE) dan Return on Assets (ROA). Kemudian jenis pengukur variabel yang digunakan adalah variabel rasio, variabel rasio menurut Bungin (2015) adalah variabel yang memiliki permulaan angka nol mutlak.

\section{Populasi dan Sampel}

Populasi dalam penelitian ini adalah perusahaan pertambangan yang terdaftar di Bursa Efek Indonesia tahun 2011, 2012, 2013, 2014, dan 2015 yang memenuhi kriteria sebagai berikut:

1. Perusahaan pertambangan yang terdaftar di Bursa Efek Indonesia dengan pengklasifikasian ICMD (Indonesian Capital Market Directory) tahun 20112015

2. Perusahaan pertambangan yang menerbitkan laporan tahunan lengkap baik Annual Report maupun laporan keuangan tahun 2011-2015

Teknik pengambilan sampel yang digunakan adalah sampling jenuh. Sampling jenuh menurut Sugiyono (2014) adalah teknik penentuan sampel bila semua anggota populasi digunakan sebagai sampel. Hal ini sering dilakukan bila jumlah populasi relatif kecil atau kurang dari 30 sampel. Maka dapat diperoleh 29 perusahaan pertambangan yang menjadi sampel penelitian.

\section{Teknik Pengumpulan Data}

Sumber data dalam penelitian ini yaitu data sekunder, Metode pengumpulan data yang digunakan adalah telaah dokumentasi atau arsip. yaitu dilakukan dengan meneliti dan memperlajari dokumen-dokumen yang relevan dengan kepentingan penelitian.

Data yang digunakan dalam penelitian ini merupakan data time series karena data penelitian tersebut berupa data rentetan waktu, yaitu data dan rasio keuangan (financial data and ratios) yang termuat dalam idx fact book dan Indonesian Capital Market Directory (ICMD) untuk periode tahun 2011-2015.

\section{Metode Analisis Data}

Menurut Sugiyono (2013:147), metode analisis data merupakan kegiatan setelah data dari seluruh responden atau sumber data lain terkumpul. Data yang telah dikumpulkan akan diolah dengan menggunakan software pengolah data, IBM SPSS Statistics. Metode analisis statistik yang digunakan untuk menganalisis data yang diperoleh antara lain metode analisis statistik deskriptif, analisis korelasi dan uji hipotesis.

Metode statistik yang digunakan untuk menguji hipotesis adalah regresi berganda (multiple regression), hal ini sesuai dengan rumusan masalah, tujuan dan hipotesis penelitian ini. Uji regresi berganda digunakan untuk menguji pengaruh debt to equity ratio dan debt to assets ratio terhadap return on equity dan pengaruh debt to equity ratio dan debt to assets ratio terhadap return on assets. Hubungan antar variabel tersebut 
dapat digambarkan dengan persamaan sebagai berikut:

$\mathrm{ROE}=\mathrm{b}_{0}+\mathrm{b}_{1} * \mathrm{DER}+\mathrm{b}_{2} * \mathrm{DAR} \quad \ldots$ model 1

$\mathrm{ROA}=\mathrm{b}_{0}+\mathrm{b}_{1} * \mathrm{DER}+\mathrm{b}_{2} * \mathrm{DAR} \quad \ldots$ model 2

Dimana :

$\begin{array}{ll}\mathrm{b}_{0} & =\text { Konstanta } \\ \mathrm{b}_{1} & =\text { Koefisien dari DER } \\ \mathrm{b}_{2} & =\text { Koefisien dari DAR } \\ \text { DER } & =\text { total utang / total ekuitas } \\ & \text { perusahaan } \\ \text { DAR } & =\text { total utang / total asset } \\ & \text { perusahaan }\end{array}$

HASIL DAN PEMBAHASAN

Analisis Statistik Deskriptif

Analisis deskriptif ini digunakan untuk menjawab perumusan masalah yang pertama dan kedua yaitu bagaimana struktur modal dan profitabilitas pada perusahaan pertambangan yang tercatat di Bursa Efek Indonesia periode tahun 2011-2015.

Tabel 1. Statistik Deskriptif Variabel X dan Y

\begin{tabular}{|l|r|r|r|r|}
\hline & \multicolumn{1}{|c|}{ Min } & Max & Mean & Std. Dev \\
\hline DER & .0058 & 2.483 & .8262 & .1044 \\
\hline DAR & .0058 & .7129 & .3949 & .0514 \\
\hline ROE & -23.389 & 37.83 & 6.882 & 13.3965 \\
\hline ROA & -14.147 & 29.01 & 4.137 & 8.1098 \\
\hline
\end{tabular}

Dimensi rasio debt to equity yang digunakan untuk mengukur struktur modal menunjukkan rata-rata sebesar 0,8262 dengan standar deviasi sebesar 0,6044 berarti tingkat variansi rasio debt to equity adalah sebesar 12,64\%. Hal ini berarti bahwa rata-rata perusahaan sampel memiliki perbandingan antara utang dengan ekuitas adalah 5:6. Hal ini menunjukkan bahwa rata-rata perusahaan pertambangan yang tercatat di Bursa Efek Indonesia periode tahun 2011-2015 lebih banyak mengumpulkan ekuitas perusahaan yang salah satunya melalui penerbitan saham perusahaan sebagai sumber pendanaan perusahaan dibandingkan dengan menerbitkan surat utang sebagai sumber pendanaan perusahaan.
Dimensi rasio debt to assets yang digunakan untuk mengukur struktur modal menunjukkan rata-rata sebesar 0,3949 dengan standar deviasi 0,1814 berarti tingkat variansi rasio debt to assets adalah sebesar $12,69 \%$. Hal ini berarti bahwa rata-rata perusahaan sampel membiayai asetnya sebesar 39,49\% dari utang perusahaan dan sisanya sebesar $60,51 \%$ aset dibiayai oleh ekuitas perusahaan.

Selanjutnya dimensi rasio return on equity equity yang digunakan untuk mengukur profitabilitas menunjukkan ratarata sebesar 6,8829\% dengan standar deviasi 13,3965 berarti tingkat variansi rasio return on equity adalah sebesar $194,63 \%$. Hal ini berarti bahwa rata-rata perusahaan sampel tidak mendapatkan pengembalian (return) terhadap ekuitasnya sebesar $6,88 \%$ dengan variansi sebesar 194,63\%, dimana standar deviasinya lebih besar pada perusahaan pertambangan yang menjadi sampel. Hal tersebut menunjukkan terdapat fluktuasi return on equity yang besar pada perusahaan pertambangan yang tercatat di Bursa Efek Indonesia periode tahun 2011-2015.

Terakhir, dimensi rasio return on assets menunjukkan rata-rata sebesar 4,1372\% dengan standar deviasi 8,1098 berarti tingkat variansi rasio return on assets adalah sebesar 196,01\%. Hal ini berarti bahwa rata-rata perusahaan sampel tidak mendapatkan pengembalian (return) terhadap asetnya sebesar $4,14 \%$ dengan variansi sebesar 196,01\%, dimana standar deviasinya lebih besar pada perusahaan pertambangan yang menjadi sampel.

\section{Analisis Korelasi}

Pada penelitian ini, analisis korelasi sederhana digunakan untuk mengetahui apakah terdapat hubungan antara variabel struktur modal yang diukur dengan debt to equity ratio dan debt to assets ratio dengan variabel profitabilitas yang diukur dengan return on equity dan return on assets, serta mengetahui seberapa kuat hubungan diantaranya. Metode yang digunakan adalah korelasi pearson product moment. Adapun 
hasil uji korelasi sederhana model regresi 1 dapat dilihat pada Tabel 2 dan uji korelasi sederhana model regresi 2 dapat dilihat pada Tabel 3.

Tabel 2. Hasil Uji Korelasi Model Regresi 1

\begin{tabular}{|l|l|r|r|r|}
\hline \multicolumn{2}{|c|}{} & \multicolumn{1}{|c|}{ DER } & \multicolumn{1}{c|}{ DAR } & \multicolumn{1}{c|}{ ROE } \\
\hline $\mathrm{D}$ & Pearson & 1 & $.949^{*}$ & - \\
$\mathrm{E}$ & Correlation & & ${ }^{*}$ & $.589^{* *}$ \\
\cline { 2 - 5 } $\mathrm{R}$ & Sig. (2-tailed) & & .000 & .000 \\
\cline { 2 - 5 } & $\mathrm{N}$ & 134 & 134 & 134 \\
\hline $\mathrm{D}$ & Pearson & $.949^{* *}$ & 1 & .547 \\
$\mathrm{~A}$ & Correlation & & & \\
\cline { 2 - 5 } $\mathrm{R}$ & Sig. (2-tailed) & .000 & & .001 \\
\cline { 2 - 5 } & $\mathrm{N}$ & 134 & 134 & 134 \\
\hline $\mathrm{R}$ & Pearson & $\mathbf{. 5 8 9}$ & $\mathbf{. 5 4 7}$ & 1 \\
$\mathrm{O}$ & Correlation & & & \\
\cline { 2 - 5 } $\mathrm{E}$ & Sig. (2-tailed) & .000 & .001 & \\
\cline { 2 - 5 } & $\mathrm{N}$ & 134 & 134 & 134 \\
\hline
\end{tabular}

Berdasarkan Tabel 2, nilai korelasi antara debt to equity ratio (DER) dengan return on equity (ROE) adalah -0,589. Sedangkan nilai korelasi antara debt to assets ratio (DAR) dengan return on equity (ROE) adalah 0,547. Mengacu pada interpretasi nilai hasil analisis korelasi menurut Bungin (2010), maka nilai korelasi antara DER dengan ROE menunjukkan keduanya memiliki hubungan negatif yang rendah sedangkan nilai korelasi antara DAR dengan ROE menunjukkan keduanya memiliki hubungan positif yang kuat.

Tabel 3. Hasil Uji Korelasi Model Regresi 2

\begin{tabular}{|c|l|r|r|r|}
\hline \multicolumn{2}{|c|}{} & \multicolumn{1}{c|}{ DER } & \multicolumn{1}{c|}{ DAR } & ROA \\
\hline D & Pearson & 1 & $.949^{* *}$ & -.525 \\
E & Correlation & & & \\
\cline { 2 - 5 } R & Sig. (2-tailed) & & .000 & .008 \\
\cline { 2 - 5 } & $\mathrm{N}$ & 134 & 134 & 134 \\
\hline $\mathrm{D}$ & Pearson & $.949^{* *}$ & 1 & .395 \\
$\mathrm{~A}$ & Correlation & & & \\
\cline { 2 - 5 } $\mathrm{R}$ & Sig. (2-tailed) & .000 & & .003 \\
\cline { 2 - 5 } & $\mathrm{N}$ & 134 & 134 & 134 \\
\hline $\mathrm{R}$ & Pearson & $\mathbf{- . 5 2 5}$ & $\mathbf{. 3 9 5}$ & 1 \\
$\mathrm{O}$ & Correlation & & & \\
\cline { 2 - 5 } $\mathrm{A}$ & Sig. (2-tailed) & .008 & .003 & \\
\cline { 2 - 5 } & $\mathrm{N}$ & 134 & 134 & 134 \\
\hline
\end{tabular}

Kemudian Tabel 2 menunjukkan nilai signifikansi sebesar 0,000 untuk korelasi antara DER dan ROE dan 0,001 untuk korelasi antara DAR dan ROE yang artinya keduanya lebih kecil dari 0,05 , maka dapat disimpulkan bahwa terdapat hubungan yang signifikan antara struktur modal yang diukur dengan DER dan DAR dengan profitabilitas yang diukur dengan ROE.

Berdasarkan Tabel 3, nilai korelasi antara antara debt to equity ratio (DER) dengan return on assets (ROA) adalah 0,525 . Sedangkan nilai korelasi antara $d e b t$ to assets ratio (DAR) dengan return on assets (ROA) adalah 0,395. Mengacu pada interpretasi nilai hasil analisis korelasi menurut Bungin (2010), maka nilai korelasi antara DER dengan ROA menunjukkan keduanya memiliki hubungan negatif yang rendah sedangkan nilai korelasi antara DAR dengan ROA menunjukkan keduanya memiliki Bunganan positif yang kuat.

Kemudian Tabel 3 menunjukkan nilai signifikansi sebesar 0,008 untuk korelasi antara DER dan ROA dan 0,003 untuk korelasi antara DAR dan ROA yang artinya keduanya lebih kecil dari 0,05, maka dapat disimpulkan bahwa terdapat hubungan yang signifikan antara struktur modal yang diukur dengan DER dan DAR dengan profitabilitas yang diukur dengan ROA.

\section{Analisis Linier Berganda}

Analisis regresi linier berganda digunakan untuk mengetahui arah hubungan antara variabel struktur modal dan variabel profitabilitas dan untuk memprediksi nilai dari variabel profitabilitas yang diukur oleh return on equity (ROE) dan return on assets (ROA) apabila nilai variabel debt to equity ratio dan debt to assets ratio mengalami kenaikan atau penurunan. Hasil uji regresi linier berganda pada penelitian ini dapat dilihat pada Tabel 4 dan Tabel 5.

Tabel 4. Hasil Uji Regresi Linier Berganda

$$
\text { Model } 1
$$

\begin{tabular}{|c|l|r|r|r|}
\hline \multirow{2}{*}{ Model } & \multicolumn{2}{|c|}{$\begin{array}{c}\text { Unstandardized } \\
\text { Coefficients }\end{array}$} & $\begin{array}{c}\text { Standardized } \\
\text { Coefficients }\end{array}$ \\
\cline { 3 - 5 } \multicolumn{2}{|c|}{} & \multicolumn{1}{|c|}{ B } & Std. Error & \multicolumn{1}{c|}{ Beta } \\
\hline \multirow{3}{*}{1} & (Constant) & $\mathbf{1 . 7 4 3}$ & 3.756 & \\
\cline { 2 - 5 } & DER & $\mathbf{- 1 3 . 0 6 4}$ & 6.049 & $\mathbf{- . 5 8 9}$ \\
\cline { 2 - 5 } & DAR & $\mathbf{4 0 . 3 4 4}$ & 20.148 & $\mathbf{. 5 4 7}$ \\
\hline
\end{tabular}


Pada Tabel 4, dapat diketahui konstanta (a) sebesar 1,743 dengan koefisien regresi untuk DER $\left(b_{1}\right)$ sebesar -13,064 dan koefisien regresi untuk DAR $\left(b_{2}\right)$ sebesar 40,344. Dari hasil tersebut, diperoleh persamaan regresi linier berganda sebagai berikut:

$$
\begin{aligned}
& \mathrm{ROE}=\mathrm{b}_{0}+\mathrm{b}_{1} * \mathrm{DER}+\mathrm{b}_{2} * \mathrm{DAR} \\
& \mathrm{ROE}=1,743-13,064 \mathrm{DER}+40,344 \mathrm{DAR}
\end{aligned}
$$

Nilai $b_{0}, b_{1}$, dan $b_{2}$ pada persamaan regresi linier berganda model 1 tersebut dapat diinterpretasikan sebagai berikut:

1. Konstanta sebesar 1.743 dapat diartikan jika DER dan DAR nilainya adalah 0 $\left(\mathrm{X}_{1}\right.$ dan $\left.\mathrm{X}_{2}=0\right)$ atau tidak ada rasio debt to equity dan debt to assets, maka return on equity nilainya hanya sebesar 1,743 .

2. Koefisien regresi variabel debt to equity ratio sebesar $-13,064$ yang artinya jika debt to equity ratio mengalami kenaikan satu satuan, maka return on equity akan mengalami penurunan sebesar 13,064 satuan. Koefisien bernilai negatif artinya terjadi hubungan negatif antara debt to equity ratio dengan return on equity, semakin naik debt to equity ratio maka semakin menurunkan rasio return on equity. Sedangkan koefisien regresi variabel debt to assets ratio sebesar 40,344 yang artinya jika debt to assets ratio mengalami kenaikan satu satuan, maka return on equity akan mengalami peningkatan sebesar 40,344 satuan. Koefisen bernilai positif artinya terjadi hubungan positif antara debt to assets ratio dengan return on equity, semakin naik debt to assets ratio maka semakin meningkatkan rasio return on equity.

Tabel 5. Hasil Uji Regresi Linier Berganda Model 2

\begin{tabular}{|l|l|r|r|r|}
\hline \multicolumn{2}{|l|}{ Model } & \multicolumn{2}{|c|}{$\begin{array}{c}\text { Unstandardized } \\
\text { Coefficients }\end{array}$} & $\begin{array}{c}\text { Standardized } \\
\text { Coefficients }\end{array}$ \\
\cline { 3 - 5 } \multicolumn{2}{|l}{} & \multicolumn{1}{c|}{ B } & Std. Error & \multicolumn{1}{c|}{ Beta } \\
\hline \multirow{3}{*}{1} & (Constant) & $\mathbf{2 . 9 9 1}$ & 2.270 & \\
\cline { 2 - 5 } & DER & $\mathbf{- 7 . 0 4 5}$ & 3.655 & $\mathbf{- . 5 2 5}$ \\
\cline { 2 - 5 } & DAR & $\mathbf{1 7 . 6 4 0}$ & 12.175 & $\mathbf{. 3 9 5}$ \\
\hline
\end{tabular}

Pada Tabel 5, dapat diketahui konstanta (a) sebesar 2,991 dengan koefisien regresi untuk DER $\left(b_{1}\right)$ sebesar -7,045 dan koefisien regresi untuk DAR $\left(b_{2}\right)$ sebesar 17,640. Dari hasil tersebut, diperoleh persamaan regresi linier berganda sebagai berikut:

$\mathrm{ROA}=\mathrm{b}_{0}+\mathrm{b}_{1} * \mathrm{DER}+\mathrm{b}_{2} * \mathrm{DAR}$ $\mathrm{ROA}=2,991-7,045 \mathrm{DER}+17,640 \mathrm{DAR}$

Nilai $b_{0}, b_{1}$, dan $b_{2}$ pada persamaan regresi linier berganda model 1 tersebut dapat diinterpretasikan sebagai berikut:

1. Konstanta sebesar 2,991 dapat diartikan jika DER dan DAR nilainya adalah 0 $\left(\mathrm{X}_{1}\right.$ dan $\left.\mathrm{X}_{2}=0\right)$ atau tidak ada rasio debt to equity dan debt to assets, maka return on assets nilainya hanya sebesar 2,991.

2. Koefisien regresi variabel debt to equity ratio sebesar $-7,045$ yang artinya jika debt to equity ratio mengalami kenaikan satu satuan, maka return on assets akan mengalami penurunan sebesar 7,045 satuan. Koefisien bernilai negatif artinya terjadi hubungan negatif antara debt to equity ratio dengan return on assets, semakin naik debt to equity ratio maka semakin menurunkan rasio return on assets. Sedangkan koefisien regresi variabel debt to assets ratio sebesar 17,640 yang artinya jika debt to assets ratio mengalami kenaikan satu satuan, maka return on assets akan mengalami peningkatan sebesar 17,640 satuan. Koefisen bernilai positif artinya terjadi hubungan positif antara debt to assets ratio dengan return on assets, semakin naik debt to assets ratio maka semakin meningkatkan rasio return on assets.

Tabel 6. Koefisien Determinasi Model Regresi 1

\begin{tabular}{|l|r|r|rr|}
\hline Model & \multicolumn{2}{|c|}{ R } & \multicolumn{1}{c|}{ R Square } & \multicolumn{2}{|c|}{$\begin{array}{c}\text { Adjusted R } \\
\text { Square }\end{array}$} \\
\hline 1 & $.646^{\mathrm{a}}$ & $\mathbf{. 4 1 7}$ & .747 \\
\hline
\end{tabular}

\section{Pengujian Koefisien Determinasi}

Koefisien determinasi digunakan untuk melihat kontribusi pengaruh yang diberikan variabel struktur modal (independen) terhadap variabel profitabilitas yang diukur oleh ROE dan ROA (dependen) dengan melihat tabel Model Summary 
seperti pada Tabel 6 dari hasil uji regresi linier berganda model regresi 1 dan pada Tabel 7 dari hasil uji regresi linier berganda model regresi 2 .

Tabel 7. Koefisien Determinasi Model Regresi 2

\begin{tabular}{|l|r|r|r|}
\hline Model & R & R Square & \multicolumn{2}{|c|}{$\begin{array}{c}\text { Adjusted R } \\
\text { Square }\end{array}$} \\
\hline 1 & $.431^{\mathrm{a}}$ & $\mathbf{. 1 8 6}$ & .372 \\
\hline
\end{tabular}

Tabel 8. Uji Hipotesis

\begin{tabular}{|c|c|c|c|}
\hline No & Hipotesis & Hasil & Nilai \\
\hline $\mathrm{H}_{1}$ & $\begin{array}{l}\text { Debt to Equity } \\
\text { Ratio (DER) dan } \\
\text { Debt to Assets } \\
\text { Ratio (DAR) } \\
\text { secara simultan } \\
\text { berpengaruh } \\
\text { signifikan } \\
\text { terhadap Return } \\
\text { on Equity (ROE) }\end{array}$ & Diterima & $\begin{array}{l}41,7 \% \\
\text { perubahan nilai } \\
\text { return on equity } \\
\text { dapat dijelaskan } \\
\text { oleh variabel } \\
\text { struktur modal } \\
\text { (DER dan } \\
\text { DAR) }\end{array}$ \\
\hline $\mathrm{H}_{2}$ & $\begin{array}{l}\text { Debt to Equity } \\
\text { Ratio (DER) dan } \\
\text { Debt to Assets } \\
\text { Ratio (DAR) } \\
\text { secara simultan } \\
\text { berpengaruh } \\
\text { signifikan } \\
\text { terhadap Return } \\
\text { on Assets (ROA) }\end{array}$ & Diterima & $\begin{array}{l}18,6 \% \\
\text { perubahan nilai } \\
\text { return on assets } \\
\text { dapat dijelaskan } \\
\text { oleh variabel } \\
\text { struktur modal } \\
\text { (DER dan } \\
\text { DAR) }\end{array}$ \\
\hline $\mathrm{H}_{3}$ & $\begin{array}{l}\text { Debt to Equity } \\
\text { Ratio (DER) dan } \\
\text { Debt to Assets } \\
\text { Ratio (DAR) } \\
\text { secara parsial } \\
\text { berpengaruh } \\
\text { signifikan } \\
\text { terhadap Return } \\
\text { on Equity (ROE) }\end{array}$ & $\begin{array}{l}\text { Ditolak } \\
\text { (hanya debt } \\
\text { to assets } \\
\text { saja yang } \\
\text { berpengaruh } \\
\text { signifikan } \\
\text { secara } \\
\text { parsial } \\
\text { terhadap } \\
\text { return on } \\
\text { equity) }\end{array}$ & - \\
\hline $\mathrm{H}_{4}$ & $\begin{array}{l}\text { Debt to Equity } \\
\text { Ratio (DER) dan } \\
\text { Debt to Assets } \\
\text { Ratio (DAR) } \\
\text { secara parsial } \\
\text { berpengaruh } \\
\text { signifikan } \\
\text { terhadap Return } \\
\text { on Assets (ROA) }\end{array}$ & $\begin{array}{l}\text { Ditolak } \\
\text { (hanya debt } \\
\text { to assets } \\
\text { saja yang } \\
\text { berpengaruh } \\
\text { signifikan } \\
\text { secara } \\
\text { parsial } \\
\text { terhadap } \\
\text { return on } \\
\text { assets) }\end{array}$ & - \\
\hline
\end{tabular}

Koefisien determinasi digunakan untuk menjawab perumusan masalah yang ketiga, yaitu seberapa besar pengaruh struktur modal terhadap profitabilitas perusahaan yang diukur oleh ROE dan ROA. Berdasarkan Tabel 6 nilai dari koefisien determinasi (R Square $/ \mathrm{R}^{2}$ ) adalah sebesar 0,417. Hal ini menandakan bahwa sebesar 0,417 atau $41,7 \%$ perubahan nilai return on equity (ROE) dapat dijelaskan oleh variabel struktur modal (DER dan DAR), sedangkan sisanya sebesar 58,3\% dipengaruhi oleh hal lain yang tidak diteliti dalam penelitian ini.

Berdasarkan Tabel 7 nilai dari koefisien determinasi (R Square/ $\mathrm{R}^{2}$ ) adalah sebesar 0,186. Hal ini menandakan bahwa sebesar 0,186 atau $18,6 \%$ perubahan nilai return on assets (ROA) dapat dijelaskan oleh variabel struktur modal (DER dan DAR), sedangkan sisanya sebesar 81,4\% dipengaruhi oleh hal lain yang tidak diteliti dalam penelitian ini.

\section{Pengujian Hipotesis}

Dalam penelitian ini dilakukan uji statistik $\mathrm{F}$ dan uji statistik $\mathrm{t}$ untuk mengetahui struktur modal berpengaruh signifikan terhadap profitabilitas perusahaan secara simultan maupun parsial. Tabel 8 menunjukkan hasil dan nilai dari uji hipotesis.

\section{KESIMPULAN DAN SARAN \\ Kesimpulan}

1. Dari hasil penelitian menunjukkan struktur modal yang diukur oleh Debt to Equity Ratio (DER) yaitu rata-rata perusahaan sampel memiliki perbandingan antara utang (debt) dengan ekuitas (equity) adalah 5:6. Hal ini menunjukkan bahwa rata-rata perusahaan pertambangan yang tercatat di Bursa Efek Indonesia periode tahun 2011-2015 lebih banyak mengumpulkan ekuitas perusahaan yang salah satunya melalui penerbitan saham perusahaan sebagai sumber pendanaan perusahaan dibandingkan dengan menerbitkan surat utang sebagai sumber pendanaan perusahaan. Kemudian struktur modal yang diukur oleh Debt to Assets Ratio (DAR) yaitu rata-rata perusahaan sampel membiayai asetnya sebesar 39,49\% dari utang perusahaan dan sisanya sebesar 
$60,51 \%$ aset dibiayai oleh ekuitas perusahaan.

2. Profitabilitas perusahaan yang diukur oleh Return on Equity menunjukkan rata-rata perusahaan sampel mendapatkan pengembalian (return) terhadap ekuitasnya sebesar $6,88 \%$, artinya perusahaan mampu mengelola modal sendiri sebesar Rp 1,- untuk menghasilkan keuntungan sebesar Rp 0,07 atau $6,88 \%$ dan profitabilitas perusahaan yang diukur oleh Return on Assets menunjukkan rata-rata perusahaan sampel mendapatkan pengembalian (return) terhadap asetnya sebesar 4,14\%, artinya perusahaan mampu mengelola setiap aset sebesar Rp 1,- untuk menghasilkan keuntungan sebesar Rp 0,04 atau 4,14\%.

3. Struktur modal memiliki pengaruh positif terhadap profitabilitas, baik itu yang ditunjukkan pada model regresi 1 maupun pada model regresi 2. variabel struktur modal (DER dan DAR) memberikan kontribusi pengaruh sebesar 0,417 atau $41,7 \%$ terhadap profitabilitas perusahaan yang diukur oleh ROE dan memberikan kontribusi pengaruh sebesar 0,186 atau $18,6 \%$ terhadap profitabilitas perusahaan yang diukur oleh ROA. Kemudian hasil penelitian menunjukkan bahwa (1) Debt to Equity Ratio (DER) dan Debt to Assets Ratio (DAR) secara simultan berpengaruh signifikan terhadap Return on Equity (ROE), hal ini dibuktikan melalui nilai koefisien regresi sebesar -13,064 untuk dimensi DER dan 40,344 untuk dimensi DAR dan P-value sebesar 0,001. (2) Debt to Equity Ratio (DER) dan Debt to Assets Ratio (DAR) secara simultan berpengaruh signifikan terhadap Return on Assets (ROA), hal ini dibuktikan melalui nilai koefisien regresi sebesar -7,045 untuk dimensi DER dan 17,640 untuk dimensi DAR dan P-value sebesar 0,029. Sedangkan struktur modal yang diukur oleh Debt to Equity Ratio (DER) dan Debt to Assets Ratio (DAR) secara parsial tidak berpengaruh signifikan terhadap profitabilitas yang diukur oleh Return on Equity dan Return on Assets.

\section{Saran}

1. Dalam menentukan struktur modal, perlu diperhatikan dampaknya bagi kenaikan maupun penurunan rasio return on equity dan return on assets karena kedua rasio tersebut merupakan salah satu indikator yang digunakan pemegang saham untuk mengukur keberhasilan bisnis yang dijalani. Dari hasil penelitian, debt to equity ratio memiliki pengaruh negatif yang signifikan terhadap return on equity maupun return on assets, sehingga perusahaan disarankan untuk menurunkan rasio debt to equity. Penurunan rasio debt to equity didapatkan dari menurukan jumlah utang dan menaikan jumlah ekuitas (modal). Dalam rangka menaikan jumlah ekuitas, perusahaan dapat menerbitkan saham baru. Dengan menerbitkan saham baru, maka jumlah equity perusahaan akan dapat bertambah. Dengan bertambahnya equity perusahaan, maka tingkat utang dapat menurun.

2. Dari hasil penelitian, return on equity dan return on assets memiliki pengaruh negatif yang signifikan terhadap rasio debt to equity dan memiliki pengaruh positif yang signifikan terhadap rasio debt to assets, sehingga dalam rangka menaikan rasio return on equity dan return on assets sebagai dimensi yang digunakan untuk mengukur variabel profitabilitas, perusahaan disarankan untuk menurunkan rasio debt to equity dan menaikkan debt to assets. Penurunan rasio debt to equity didapatkan dari menurukan jumlah utang dan menaikan jumlah ekuitas (modal) sedangkan kenaikan rasio debt to assets didapatkan dari memaksimalkan utang perusahaan agar digunakan untuk membiayai aset perusahaan. 
DAFTAR PUSTAKA

Addae, A. A., \& Baasi, M. N. (2013). The Effects of Capital Structure on Profitability of Listed Firms in Ghana. European Journal of Business and Management, 215-229.

Brigham, E. F., \& Houston, J. F. (2011). Essentials of Financial Management Edisi II Buku 2. (A. A. Yulianto, Trans.) Jakarta: Salemba Empat.

Bungin, B. 2010. Metode Penelitian Kuantitatif. Jakarta: Kencana Prenada Media Group.

Bungin, B. (2015). Metodologi Penelitian Sosial dan Ekonomi: Format-format Kuantitatif dan Kualitatif untuk Studi Sosiologi, Kebijakan Publik, Komunikasi, Manajemen, dan Pemasaran. Jakarta: Prenadamedia Group.

Fahmi, I. (2013). Analisis Laporan Keuangan. Bandung: Alfabeta.

Gitman, L. J., \& Zutter, C. J. (2015). Principles of Managerial Finance. England: Pearson Education.

Kasmir. (2008). Analisis Laporan Keuangan. Jakarta: PT Rajagrafindo Persada.

Mulyawan, S. (2015). Manajemen Keuangan. Bandung: CV Pustaka Setia.

Nazir. (2013). Metode Penelitian. Bogor: Penerbit Ghalia Indonesia.

Prihadi, T. (2013). Analisis Laporan Keuangan Lanjutan: Proyeksi \& Evaluasi. Jakarta: Penerbit PPM.

Ross, S. A., Westerfield, R. W., Jordan, B. D., Lam, J., \& Tan, R. (2015). Pengantar Keuangan Perusahaan Edisi Global Asia Buku 1. (R. Saraswati, Trans.) Jakarta: Penerbit Salemba Empat.

Salawu, R. O. (2009). The Effect of Capital Structure on Profitability: An Empirical Analysis of Listed Firms in Nigeria. The International Journal of Business and Finance Research, 121-129.

Sjahrial, D., \& Purba, D. (2013). Analisis Laporan Keuangan. Jakarta: Mitra Wacana Media.
Sudana, I. M. (2011). Manajemen Keuangan Perusahaan Teori dan Praktik. Surabaya: Penerbit Erlangga.

Sugiyono. (2013). Metode Penelitian Kuantitatif, Kualitatif dan $R$ \& $D$. Bandung: Alfabeta.

Sugiyono. (2014). Metode Penelitian Kuantitatif Kualitatif dan $R \& D$. Bandung: Alfabeta.

Velnampy, T., \& Niresh, J. A. (2012). The Relationship between Capital Structure \& Profitability. Global Journal of Management and Business Research, 12(13). 